Harry.et.al. Pembuatan Kitosan Perak Sebagai Adsorben Untuk Menurunkan Kadar Logam Besi (Fe) Dan Zink (Zn) Pada Air Sungai Desa Kopas Kecamatan Simpang Empat Kabupaten Asahan

\title{
PEMBUATAN KITOSAN PERAK SEBAGAI ADSORBEN UNTUK MENURUNKAN KADAR LOGAM BESI (Fe) DAN ZINK (Zn) PADA AIR SUNGAI DESA KOPAS KECAMATAN SIMPANG EMPAT KABUPATEN ASAHAN
}

\author{
Harry Agusnar'), Chairuddin ${ }^{2)}$, Nabilah Hannani ${ }^{3)}$ \\ ${ }^{1)}$ Departemen Kimia FMIPA Universitas Sumatera Utara \\ Email : harryagusnar@yahoo.com \\ ${ }^{2)}$ Departemen Kimia FMIPA Universitas Sumatera Utara \\ Email: chairuddin2@usu.ac.id \\ ${ }^{3)}$ Departemen Kimia FMIPA Universitas Sumatera Utara \\ Email : harryagusnar@yahoo.com
}

\begin{abstract}
ABSTRAK
Penelitian pembuatan kitosan yang dimodifikasi dengan larutan $\mathrm{AgNO}_{3}$ menjadi kitosan perak sebagai adsorben untuk menurunkan kadar logam besi (Fe) dan zink ( $\mathrm{Zn}$ ) pada air sungai desa Kopas kecamatan simpang empat kabupaten asahan telah dilakukan. Pada penelitian ini, didahului dengan pembuatan kitosan perak dengan melarutkan kitosan komersial dan asam asetat 1\% serta dicampurkan dengan larutan $\mathrm{AgNO}_{3}$ 0,5 $\mathrm{M}$ dengan rasio 2:1 lalu diteteskan kedalam larutan $\mathrm{NaOH} 2 \mathrm{M}$ yang kemudian membentuk gel (bead) berwarna hitam. Kitosan perak yang telah dikeringkan dimasukkan ke dalam kolom, lalu ditambahkan dengan $50 \mathrm{~mL}$ sampel yang telah didestruksi dan sudah diketahui kadar logam Fe dan Zn sebesar 1,5175 mg/L dan 0,7218 mg/L. Didiamkan berdasarkan variasi waktu kontak selama 30, 45, dan 60 menit. Penentuan penurunan kadar logam yang telah di adsorbsi oleh kitosan perak dilakukan dengan menggunakan Spektrofotometri Serapan Atom (SSA). Hasil penelitian menunjukkan bahwa pada proses adsorpsi diperoleh persentase penyerapan logam Fe 82,154\% dan logam Zn 84,871 \% pada waktu kontak optimum penyerapan yaitu 45 menit.
\end{abstract}

Kata Kunci : Adsorben, Kitosan Perak, Logam Besi (Fe), Logam Zink (Zn), SSA.

\section{PENDAhuluan}

Air merupakan bahan yang sangat vital yang tidak dapat dipisahkan dari seluruh aktivitas kehidupan mahkluk hidup di bumi ini. Keseluruhan jumlah dari 40 juta mil kubik air yang berada di planet bumi ini, baik yang di dalam maupun permukaan ternyata hanya $0,5 \%$ atau 0,2 juta mil kubik yang secara langsung dapat digunakan. Sisanya, yaitu $97 \%$ berbentuk air laut dan $2,5 \%$ berbentuk salju dan es abadi yang dalam keadaan cair baru dapat digunakan (Suriawiria, 2005).

Berdasarkan peraturan Menkes Nomor 416/MEN.KES/PER/IX/1990 tentang
Syarat-syarat dan Pengawasan Kualitas Air yang disebut sebagai air minum adalah air yang melalui proses pengolahan yang memenuhi syarat kesehatan dan dapat langsung di minum. Sedangkan air bersih adalah air yang digunakan untuk keperluan sehari-hari yang kualitasnya memenuhi syarat kesehatan dan dapat diminum apabila telah dimasak.

Sungai memiliki peran strategis secara ekonomi bagi masyarakat dan pembangunan daerah, diantaranya sebagai sumber air minum, bahan baku industri, sarana budidaya perikanan, irigasi pertanian, dan pembangkit listrik daerah. Sungai juga 
Harry.et.al. Pembuatan Kitosan Perak Sebagai Adsorben Untuk Menurunkan Kadar Logam Besi (Fe) Dan Zink (Zn) Pada Air Sungai Desa Kopas Kecamatan Simpang Empat Kabupaten Asahan

memiliki peran penting secara ekologi sebagai sebuah ekosistem dengan seluruh kesatuan didalamnya. Sebagai sebuah ekosistem perairan terbuka yang mengalir, sungai mendapat input dari luar sejak di hulu hingga ke hilir. Input tersebut dapat berupa limbah sisa industri dan limbah domestik maupun input dari gangguan bencana alam. Hal tersebut dapat menurunkan kualitas air sungai, mempengaruhi biota perairan, dan secara luas merugikan kehidupan manusia (Imroatushshoolikhah, 2014).

Erupsi gunung yang berupa aliran larva, hujan abu vulkanik, banjir lahar dingin merupakan batuan dan mineral yang berasal dari gunung berapi yang mengandung logam-logam mineral, logam berat maupun unsur radionuklida alam dengan isotop $\mathrm{K}, \mathrm{U}$, dan Th yang umumnya terdapat di dalam magma atau material yang dikeluarkan gunung berapi (Ardianto, 2009).

Logam berat didefinisikan sebagai logam yang memiliki densitas yang tinggi dan merupakan pencemar yang banyak dijumpai baik di lingkungan darat maupun perairan. Logam berat memiliki pengaruh pada kehidupan organisme lingkungan, karena bersifat racun dan dapat menyebabkan kematian apabila jumlahnya melewati ambang batas yang telah ditetapkan. Maka dari itu, kandungan logam berat di lingkungan dapat dikurangi dengan cara menjerapnya yaitu dengan menggunakan kitosan (Karthikeyan et al., 2004).

Kitosan adalah senyawa polimer alam turunan kitin yang diisolasi dari limbah perikanan, seperti kulit udang, cangkang kepiting, cumi-cumi, serta belangkas dengan kandungan kitin hingga 90 persen. Senyawa kitin dan kitosan ini dapat diolah dan dimanfaatkan sebagai bahan penyerap logam-logam berat yang dihasilkan oleh limbah industri. Hal ini dimungkinkan karena senyawa kitin dan kitosan mempunyai sifat sebagai bahan pengemulsi koagulasi, reaktifitas kimia yang tinggi dan menyebabkan sifat polielektrolit kation sehingga dapat berperan sebagai penukar ion (ion exchanger) dan dapat berfungsi sebagai adsorben terhadap logam berat (Agusnar, 2006).

Agusnar (2006) telah melakukan penelitian mengenai Penggunaan Kitosan dari Tulang Rawan Cumi-Cumi (Loligo pealli) untuk Menurunkan Kadar Ion Logam, dimana hasilnya kitosan mampu menyerap logam kadmium secara optimum pada waktu kontak 75 menit dengan \% penyerapan sebesar $35,75 \%$.

Khairuni, M (2017) telah melakukan penelitian menggunakan modifikasi kitosan menjadi komposit kitosan $\mathrm{CuO}$ sebagai adsorben untuk menyerap kadar logam Besi $(\mathrm{Fe})$, Mangan (Mn) dan Zink ( $\mathrm{Zn})$ pada air sungai Belawan Medan.

Daulay, A.M. (2011) telah melakukan penelitian penggunaan kitosan magnetic nanopartikel untuk menyerap logam kadmium $(\mathrm{Cd})$ dan tembaga $(\mathrm{Cu})$ dengan menggunakan Spektrofotometer Serapan Atom (SSA) dimana daya serap optimum pada logam Cd sebesar 90,04\% dan pada logam $\mathrm{Cu}$ sebesar $99,12 \%$ dengan waktu kontak 30 menit.

Maslan (2011) telah melakukan penelitian efektivitas penyerapan Logam Besi $(\mathrm{Fe})$ dan Logam Natrium (Na) oleh kitosan nanopartikel pada limbah cair detergen dimana daya serap optimum logam Fe sebesar 90,03\% dan logam $\mathrm{Na}$ sebesar $96,43 \%$.

Berdasarkan latar belakang dan penelitian yang telah dilakukan sebelumnya, peneliti tertarik untuk melakukan penelitian dengan judul "Pembuatan Kitosan Perak Sebagai Adsorben Untuk Menurunkan Kadar Logam Besi (Fe) dan Zink (Zn) Pada Air Sungai Desa Kopas Kecamatan Simpang Empat Kabupaten Asahan". 
Harry.et.al. Pembuatan Kitosan Perak Sebagai Adsorben Untuk Menurunkan Kadar Logam Besi (Fe) Dan Zink (Zn) Pada Air Sungai Desa Kopas Kecamatan Simpang Empat Kabupaten Asahan

\section{METODOLOGI PENELITIAN}

\subsection{Alat-alat}

Alat-alat yang digunakan dalam penelitian ini antara lain: Alat-alat gelas, Bola Karet, Spatula, Cawan Petri, Kertas Saring, Botol Vial, Pompa Injeksi, Pipet Volume, Pipet Tetes, Alat Kolom, Neraca Analitis, Oven, Mechanical Stirrer, $\mathrm{pH}$ Universal, Hot Plate, Alat Uji SSA, FT-IR.

\subsection{Bahan-bahan}

Bahan-bahan yang digunakan dalam penelitian ini antara lain : Kitosan, $\mathrm{NaOH}$ pellet, $\mathrm{AgNO}_{3(\mathrm{~s})}, \mathrm{CH}_{3} \mathrm{COOH}$ glacial, Aquadest, $\mathrm{HNO}_{3(\mathrm{p})}$, Larutan Standar $\mathrm{Fe}$, Larutan Standar Zn, Air Sungai Desa Kopas.

\subsection{Prosedur Penelitian}

\subsubsection{Pembuatan Larutan Pereaksi}

\section{a. Larutan Asam Asetat 1\% (v/v)}

Sebanyak $10 \mathrm{~mL}$ asam asetat glacial dimasukkan ke dalam labu takar $1000 \mathrm{~mL}$. Kemudian diencerkan dengan akuades sampai garis tanda, lalu dihomogenkan.

\section{b. Larutan $\mathrm{NaOH} 2 \mathrm{M}(\mathrm{b} / \mathrm{v})$}

Sebanyak 40 g $\mathrm{NaOH}$ pellet dimasukkan ke dalam Beaker glass. Ditambahkan $500 \mathrm{~mL}$ akuades. Lalu diaduk sampai homogen sehingga diperoleh larutan $\mathrm{NaOH} 2 \mathrm{M}$.

\section{c. Larutan $\mathrm{AgNO}_{3}$ 0,5 M (b/v)}

Sebanyak 21,22 g Kristal $\mathrm{AgNO}_{3}$ dimasukkan ke dalam Beaker glass. Dilarutkan dengan akuades, dimasukkan kedalam labu takar 250 $\mathrm{mL}$ kemudian ditambahkan akuades sampai garis tanda sehingga diperoleh larutan $\mathrm{AgNO}_{3}$ 0,5 M.

\subsubsection{Pembuatan Larutan Kitosan}

Sebanyak 1 g kitosan dilarutkan ke dalam larutan asetat $1 \%(b / v)$ sebanyak $100 \mathrm{~mL}$. Lalu diaduk sampai homogen sehingga diperoleh larutan kitosan yang kental.

\subsubsection{Pembuatan Kitosan Perak}

Larutan kitosan dimasukkan kedalam Beaker glass. Kemudian ditambahkan dengan larutan $\mathrm{AgNO}_{3}$ 0,5 $\mathrm{M}$ dengan rasio 2:1 hingga diperoleh larutan kental. Larutan kental kemudian dimasukkan ke dalam pompa injeksi dan diteteskan kedalam larutan $\mathrm{NaOH} 2 \mathrm{M}$ sebanyak 1 L hingga terbentuk butiran hitam. Selanjutnya didiamkan selama 1 malam. Lalu disaring dan dicuci dengan akuades dan dipanaskan sampai kering hingga temperatur $80^{\circ} \mathrm{C}$. Disimpan pada suhu ruang.

\subsubsection{Preparasi Larutan Sampel}

Diukur sebanyak $250 \mathrm{~mL}$ sampel Air Sungai Desa Kopas kemudian dimasukkan ke dalam Beaker glass 500 $\mathrm{mL}$, ditambahkan $\mathrm{HNO}_{3(\mathrm{p})}$ hingga $\mathrm{pH}=3$. Diambil sebanyak $100 \mathrm{~mL}$ kemudian dimasukkan kedalam Beaker glass dan ditambahkan $5 \mathrm{~mL} \mathrm{HNO}_{3(\mathrm{p})}$. Dipanaskan perlahan diatas hotplate hingga volume 15-20 mL, kemudian ditambahkan 50 $\mathrm{mL}$ akuades dan dimasukkan kedalam labu takar $100 \mathrm{~mL}$ melalui kertas saring. Diencerkan dengan akuades hingga garis tanda dan diaduk hingga homogen.

\subsubsection{Penentuan Kandungan Besi (Fe) Secara Spektrofotometri Serapan Atom (SSA)}

Larutan sampel yang telah didestruksi, dianalisa secara kuantitatif dengan mengukur absorbansinya pada $\lambda_{\text {spesifik }}=$ $248,3 \mathrm{~nm}$ dengan menggunakan alat Spektrofotometer Serapan Atom (SSA). 
Harry.et.al. Pembuatan Kitosan Perak Sebagai Adsorben Untuk Menurunkan Kadar Logam Besi (Fe) Dan Zink (Zn) Pada Air Sungai Desa Kopas Kecamatan Simpang Empat Kabupaten Asahan

2.3.6 Penentuan Kandungan Zink (Zn) Secara Spektrofotometri Serapan Atom (SSA)

Larutan sampel yang telah didestruksi, dianalisa secara kuantitatif dengan mengukur absorbansinya pada $\lambda_{\text {spesifik }}=$ 213,9 $\mathrm{nm}$ dengan menggunakan alat Spektrofotometer Serapan Atom (SSA).

\subsubsection{Penentuan Waktu Kontak Optimum pada Kitosan Perak}

Larutan sampel Air Sungai Desa Kopas yang telah didestruksi dimasukkan ke dalam kolom yang telah berisi $10 \mathrm{~g}$ kitosan perak, didiamkan berdasarkan variasi waktu kontak yaitu 30, 45, dan 60 menit. Kemudian dibuka tutup kolom dan ditampung dengan botol vial. Selanjutnya diuji absorbansinya dengan menggunakan Spektrofotometri Serapan Atom.

\section{HASIL DAN PEMBAHASAN}

\subsection{Hasil Penelitian}

\subsubsection{Data Absorbansi Larutan Standar Besi (Fe)}

Tabel 1. Data Absorbansi Larutan Standar Besi (Fe)

\begin{tabular}{ccc}
\hline No & $\begin{array}{c}\text { Konsentrasi } \\
(\mathbf{m g} / \mathbf{L})\end{array}$ & $\begin{array}{c}\text { Absorbansi } \\
\text { Rata-rata }\end{array}$ \\
\hline 1 & 0,0 & 0,0000 \\
2 & 0,2 & 0,0264 \\
3 & 0,4 & 0,0438 \\
4 & 0,6 & 0,0620 \\
5 & 0,8 & 0,0874 \\
6 & 1,0 & 0,1092 \\
\hline
\end{tabular}

Data absorbansi yang diperoleh untuk suatu seri larutan standar $\mathrm{Fe}$ diplotkan terhadap konsentrasi larutan standar sehingga diperoleh kurva kalibrasi berupa garis linear seperti pada gambar 1 berikut ini:

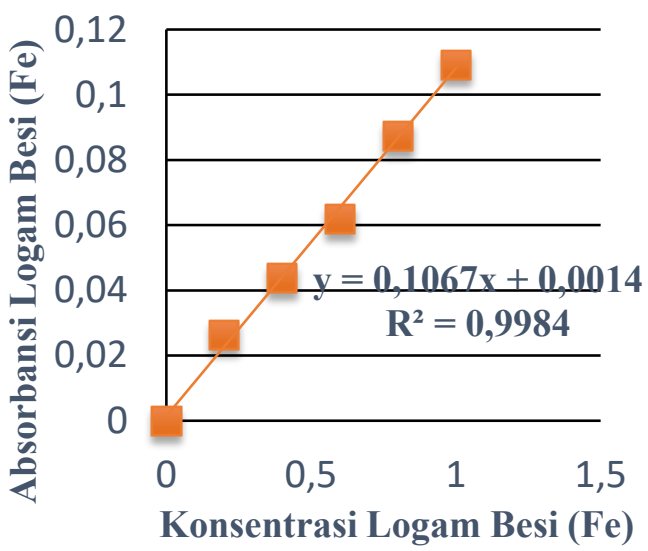

Gambar 1. Kurva Kalibrasi Larutan Seri Standar Fe

\subsubsection{Data Absorbansi Larutan Standar Zink (Zn)}

Tabel 2. Data Absorbansi Larutan Standar Zink (Zn)

\begin{tabular}{ccc}
\hline No & $\begin{array}{c}\text { Konsentrasi } \\
(\mathbf{m g} / \mathbf{L})\end{array}$ & $\begin{array}{c}\text { Absorbansi } \\
\text { Rata-rata }\end{array}$ \\
\hline 1 & 0,0 & 0,0000 \\
2 & 0,2 & 0,1508 \\
3 & 0,4 & 0,2779 \\
4 & 0,6 & 0,4109 \\
5 & 0,8 & 0,5118 \\
6 & 1,0 & 0,5932 \\
\hline
\end{tabular}

Data absorbansi yang diperoleh untuk suatu seri larutan standar Zn diplotkan terhadap konsentrasi larutan standar sehingga diperoleh kurva kalibrasi berupa garis linear seperti pada gambar 2. berikut ini: 
Harry.et.al. Pembuatan Kitosan Perak Sebagai Adsorben Untuk Menurunkan Kadar Logam Besi (Fe) Dan Zink (Zn) Pada Air Sungai Desa Kopas Kecamatan Simpang Empat Kabupaten Asahan

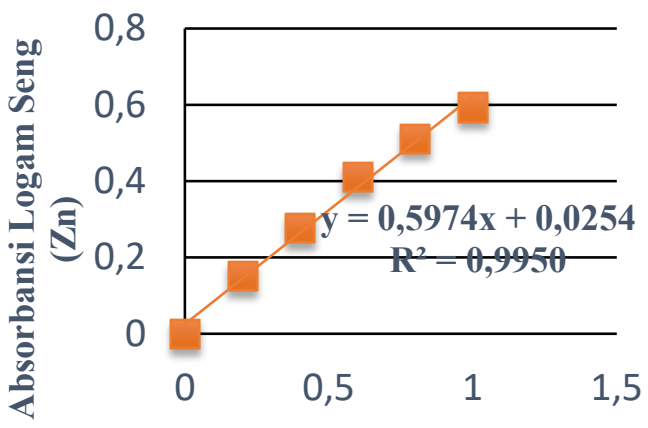

Konsentrasi Logam Seng (Zn)

Gambar 2. Kurva Kalibrasi Larutan Seri tandar Zn

\subsubsection{Penentuan Persen Adsorpsi Logam Fe}

Tabel 3. Data Penurunan Kadar Logam Fe dan Persentase Adsorpsi Berdasarkan Variasi Waktu Kontak

\begin{tabular}{|c|c|c|c|c|}
\hline \multirow{2}{*}{$\begin{array}{l}\text { Wakt } \\
\text { u } \\
\text { Kont } \\
\text { ak } \\
\text { (Men } \\
\text { it) }\end{array}$} & \multicolumn{2}{|c|}{$\begin{array}{c}\text { Konsentrasi } \\
(\mathrm{mg} / \mathrm{L})\end{array}$} & \multirow{2}{*}{$\begin{array}{c}\text { Konse } \\
\text { ntrasi } \\
\text { yang } \\
\text { tersera } \\
\mathrm{p} \\
(\mathrm{mg} / \mathrm{L})\end{array}$} & \multirow{2}{*}{$\begin{array}{l}\text { Persenta } \\
\text { se }(\%) \\
\text { Penurun } \\
\text { an } \\
\text { Konsent } \\
\text { rasi }\end{array}$} \\
\hline & $\begin{array}{c}\text { Sebelu } \\
\text { m } \\
\text { Penam } \\
\text { bahan }\end{array}$ & $\begin{array}{l}\text { Setel } \\
\text { ah } \\
\text { Pena } \\
\text { mbah } \\
\text { an }\end{array}$ & & \\
\hline 30 & 1,5175 & $\begin{array}{c}0,52 \\
12\end{array}$ & 0,9963 & 65,654 \\
\hline 45 & 1,5175 & $\begin{array}{c}0,27 \\
08\end{array}$ & 1,2467 & 82,154 \\
\hline 60 & 1,5175 & $\begin{array}{c}0,44 \\
36\end{array}$ & 1,0739 & 70,767 \\
\hline
\end{tabular}
penentuan $\%$ adsorpsi untuk waktu kontak optimum dengan kitosan perak adalah:

$$
\begin{gathered}
\% \text { Adsorpsi }= \\
\frac{\text { Konsentrasi Awal-Konsentrasi Akhir }}{\text { Konsentrasi Awal }} \\
\begin{array}{c}
\text { x } 100 \% \\
1,5175-0,2708
\end{array} \\
\begin{array}{c}
1,5175 \\
82,154 \%
\end{array}
\end{gathered}
$$

\subsubsection{Penentuan Persen Adsorpsi

\begin{tabular}{|c|c|c|c|c|}
\hline \multirow{3}{*}{$\begin{array}{l}\text { Wakt } \\
\text { u } \\
\text { Kont } \\
\text { ak } \\
\text { (Men } \\
\text { it) }\end{array}$} & \multicolumn{2}{|c|}{$\begin{array}{c}\text { Konsentrasi } \\
(\mathrm{mg} / \mathrm{L})\end{array}$} & \multirow{3}{*}{$\begin{array}{c}\text { Konse } \\
\text { ntrasi } \\
\text { yang } \\
\text { tersera } \\
\mathrm{p} \\
(\mathrm{mg} / \mathrm{L})\end{array}$} & \multirow{3}{*}{$\begin{array}{c}\text { Persenta } \\
\text { se }(\%) \\
\text { Penurun } \\
\text { an } \\
\text { Konsent } \\
\text { rasi }\end{array}$} \\
\hline & $\begin{array}{c}\text { Sebelu } \\
\text { m }\end{array}$ & $\begin{array}{l}\text { Setel } \\
\text { ah }\end{array}$ & & \\
\hline & $\begin{array}{l}\text { Penam } \\
\text { bahan }\end{array}$ & $\begin{array}{c}\text { Pena } \\
\text { mbah } \\
\text { an }\end{array}$ & & \\
\hline 30 & 0,7218 & $\begin{array}{c}0,34 \\
54\end{array}$ & 0,3764 & 52,147 \\
\hline 45 & 0,7218 & $\begin{array}{c}0,10 \\
92\end{array}$ & 0,6126 & 84,871 \\
\hline 60 & 0,7218 & $\begin{array}{c}0,21 \\
59\end{array}$ & 0,5059 & 70,088 \\
\hline
\end{tabular} Logam Zn}

Tabel 4. Data Penurunan Kadar Logam Zn dan Persentase Adsorpsi Berdasarkan Variasi Waktu Kontak maka penentuan $\%$ adsorpsi untuk waktu kontak optimum dengan kitosan perak adalah:

$\%$ Adsorpsi $=$

Konsentrasi Awal-Konsentrasi Akhir

$$
\begin{gathered}
\text { Konsentrasi Awal } \\
\mathrm{x} 100 \% \\
\text { \% Adsorpsi }=\frac{0,7218-0,1092}{0,7218} \times 100 \%= \\
84,871 \%
\end{gathered}
$$

\subsubsection{Penentuan Berat Ekuivalen Adsorpsi Logam Fe}

Dari data hasil pengukuran, maka penentuan berat ekuivalen adsorpsi untuk waktu kontak optimum dengan kitosan perak adalah:

Grek Kitosan Perak $\approx$ Grek Logam Fe $10 \mathrm{~g} / 50 \mathrm{~mL} \approx 1,2467 \mathrm{mg} / 1000 \mathrm{~mL}$ $10 \mathrm{~g} / 50 \mathrm{~mL} \approx 0,06 \mathrm{mg} / 50 \mathrm{~mL}$ 
Harry.et.al. Pembuatan Kitosan Perak Sebagai Adsorben Untuk Menurunkan Kadar Logam Besi (Fe) Dan Zink (Zn) Pada Air Sungai Desa Kopas Kecamatan Simpang Empat Kabupaten Asahan

\subsubsection{Penentuan Berat Ekuivalen Adsorpsi Logam Zn}

Dari data hasil pengukuran, maka penentuan berat ekuivalen adsorpsi untuk waktu kontak optimum dengan kitosan perak adalah:

Grek Kitosan Perak $\approx$ Grek Logam Zn $10 \mathrm{~g} / 50 \mathrm{~mL} \approx 0,6126 \mathrm{mg} / 1000 \mathrm{~mL}$ $10 \mathrm{~g} / 50 \mathrm{~mL} \approx 0,03 \mathrm{mg} / 50 \mathrm{~mL}$

\subsubsection{Data FT-IR Kitosan Komersial}

DSHIMADZU

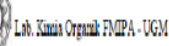

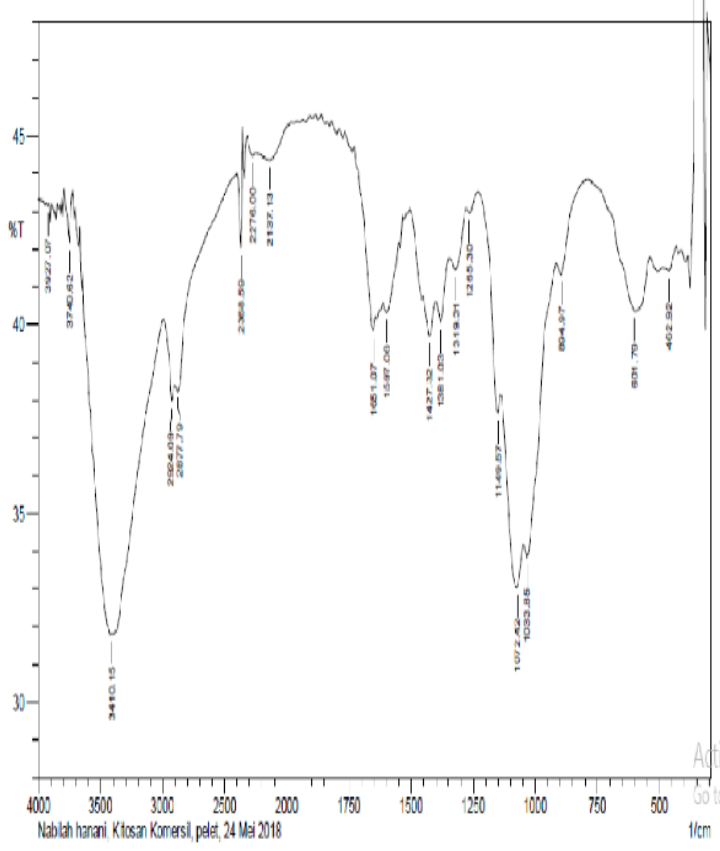

Gambar 3. Spektrum FT-IR Kitosan Komersial
Tabel 5. Data Spektrum FT-IR Kitosan Komersial

\begin{tabular}{cc}
\hline $\begin{array}{c}\text { Bilangan } \\
\text { Gelombang } \\
\left(\mathrm{cm}^{-1}\right)\end{array}$ & Gugus Fungsi \\
\hline 3410,15 & $\begin{array}{c}\text { O-H tumpang tindih } \\
\text { dengan N-H }\end{array}$ \\
2924,09 & $\mathrm{C}-\mathrm{H}$ \\
1651,07 & $\mathrm{C}=\mathrm{O}$ \\
1597,06 & $\mathrm{~N}-\mathrm{H}$ \\
1427,32 & $\mathrm{C}=\mathrm{C}$ \\
1381,03 & $\mathrm{C}-\mathrm{N}$ \\
1072,42 & $\mathrm{C}-\mathrm{O}$ \\
\hline & (Sorrell, 1998)
\end{tabular}

\subsubsection{Data FT-IR Kitosan Perak}

甲SHIMADZU

(4)

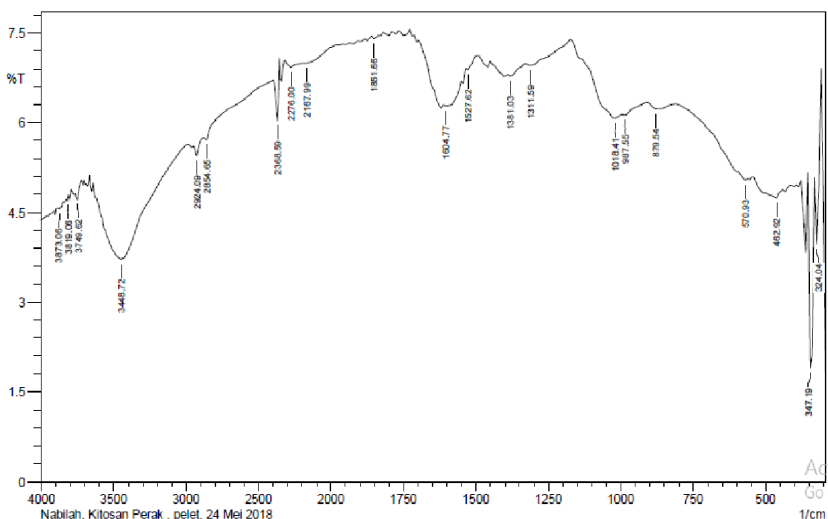

Gambar 4. Spektrum FT-IR Kitosan

Perak

Tabel 3.6. Data Spektrum FT-IR Kitosa Perak

\begin{tabular}{cc}
\hline $\begin{array}{c}\text { Bilangan } \\
\text { Gelombang }( \\
\left.\mathrm{cm}^{-1}\right)\end{array}$ & Gugus Fungsi \\
\hline 3448,72 & $\begin{array}{c}\text { O-H tumpang tindih } \\
\text { dengan N-H }\end{array}$ \\
2924,09 & $\mathrm{C}-\mathrm{H}$ \\
1604,77 & $\mathrm{C}=\mathrm{O}$ \\
1597,06 & $\mathrm{~N}-\mathrm{H}$ \\
1527,62 & $\mathrm{~N}-\mathrm{Ag}$ \\
1381,03 & $\mathrm{C}-\mathrm{N}$ \\
\hline & (Sorrell, 1998)
\end{tabular}


3.1.9 Reaksi Kitosan Komersial menjadi Kitosan Perak (Junaidi, dkk. 2013)

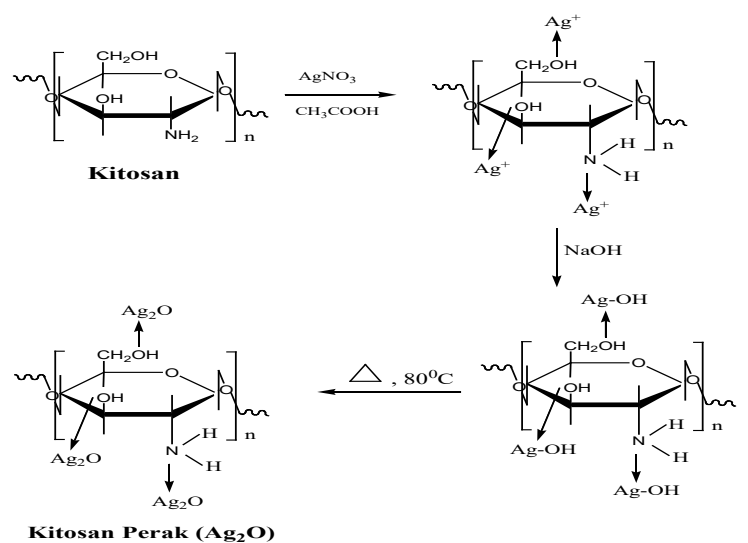

\subsubsection{Reaksi Kitosan Perak dengan Ion Logam $\mathrm{Fe}^{2+}$ dan $\mathrm{Zn}^{2+}$}
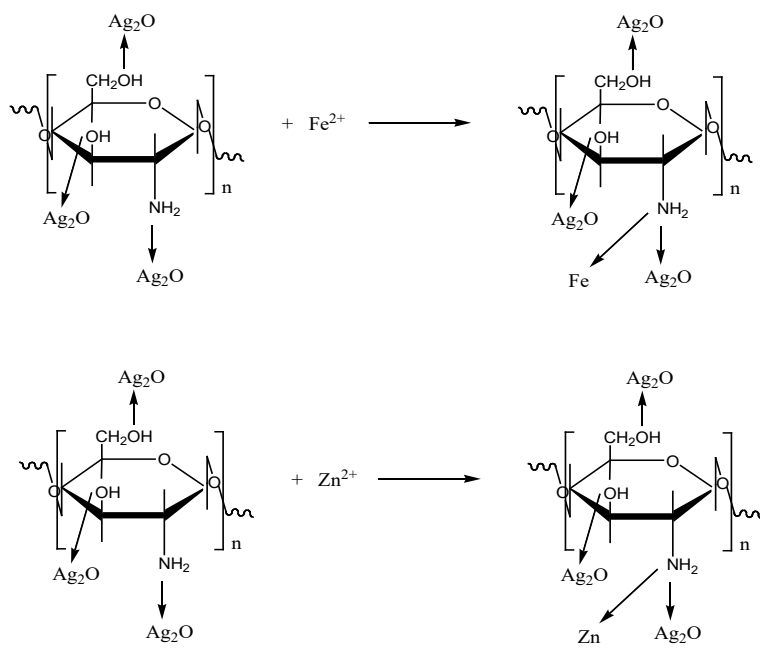

\subsection{PEMBAHASAN}

\subsubsection{Analisa Gugus Fungsi dengan menggunakan FT-IR}

Analisa dengan spektroskopi FT-IR ini dapat digunakan sebagai informasi mengenai perubahan gugus yang mengidentifikasi adanya interaksi secara kimia.

Berdasarkan tabel 3.5 dan 3.6 serta gambar spektrum pada (gambar 3.3 dan 3.4) menunjukkan Spektrum infra merah dari kitosan komersial dan kitosan perak tidak terjadi perubahan ikatan pada gugus fungsi kitosan, yang terjadi hanya perubahan pada bentuk fisiknya saja. Hal ini dikarenakan pada pembuatan kitosan digunakan asam asetat yang berfungsi untuk melarutkan dan meningkatkan viskositas larutan kitosan dan $\mathrm{NaOH} 2 \mathrm{M}$ yang berfungsi pembentuk gel, adapun perbedaan lain yang dapat dilihat berdasarkan perubahan nilai transmitasi yang menunjukkan kuantitas dari gugus tersebut.

Berdasarkan gambar 3 dan tabel 5 menampilkan spektrum FT-IR dari kitosan komersial. Pada spektrum ini terdapat gugus $\mathrm{O}-\mathrm{H}$ dengan panjang gelombang $3410,15 \mathrm{~cm}^{-1}$ dengan tampilan pita yang tajam dan lebar. Pada daerah panjang gelombang ini, seharusnya juga memunculkan pita untuk gugus $\mathrm{N}-\mathrm{H}$ dari struktur kitosan komersial, akan tetapi tidak terlihat karena bertumpang tindih dengan uluran pita dari gugus $\mathrm{O}-\mathrm{H}$. Keberadaan gugus N-H juga bisa kita perhatikan dari tekukan yang terdapat pada panjang gelombang $1597,06 \mathrm{~cm}^{-1}$ yang menandakan adanya gugus $\mathrm{N}-\mathrm{H}$ bending. Pada panjang gelombang $1427,32 \mathrm{~cm}^{-1}$ menunjukkan adanya gugus-gugus alkana sekunder $-\mathrm{CH}_{2}-$ (bending).

Pada pembentukan kitosan perak, data FT-IR dan spektrumnya dapat diamati pada gambar 4 dan tabel 6 . Serapan pada bilangan gelombang $3500-3100 \mathrm{~cm}^{-1}$ tidak terdapat puncak yang spesifik karena pada daerah ini terdapat uluran yang bertumpang tindih antara gugus $\mathrm{O}-\mathrm{H}$ dan gugus N-H yang memiliki daerah pergeseran yang lebih lebar dikarenakan atom $\mathrm{N}$ pada gugus $\mathrm{N}-\mathrm{H}$ telah terikat dengan perak. Uluran $\mathrm{N}-\mathrm{H}$ yang telah terikat dengan perak juga dapat diperjelas dengan adanya tekukan yang mengalami pergeseran ke bilangan gelombang yang lebih kecil yaitu $1597,06 \mathrm{~cm}^{-1}$ menjadi 1527,62 
Harry.et.al. Pembuatan Kitosan Perak Sebagai Adsorben Untuk Menurunkan Kadar Logam Besi (Fe) Dan Zink (Zn) Pada Air Sungai Desa Kopas Kecamatan Simpang Empat Kabupaten Asahan

$\mathrm{cm}^{-1}$ akibat besarnya masa tereduksi dan mengikat senyawa kompleks.

3.2.2 Adsorpsi Ion Logam Besi $\left(\mathrm{Fe}^{2+}\right)$ dan Zink $\left(\mathrm{Zn}^{2+}\right)$ dengan Kitosan Perak Berdasarkan Waktu Kontak Optimum

Penentuan kadar logam Besi (Fe) dan Zink (Zn) dalam larutan sampel air Sungai Kopas sebelum dan setelah penambahan kitosan perak dengan menentukan waktu kontak optimum dilakukan dengan mengukur nilai absorbansi dan konsentrasi menggunakan alat Spektrofotometer Serapan Atom.

Dari hasil penelitian bahwa persentase $(\%)$ penurunan konsentrasi ion Besi $\left(\mathrm{Fe}^{2+}\right)$ pada larutan sampel air Sungai Kopas sebelum penambahan kitosan perak memiliki konsentrasi $1,5175 \mathrm{mg} / \mathrm{L}$ dan setelah penambahan kitosan perak konsentrasi berkurang menjadi 0,$5212 ; 0,2708$; dan 0,4436 $\mathrm{mg} / \mathrm{L}$ dengan variasi waktu kontak 30 ; 45; dan 60 menit. Dengan kata lain, persentase penurunan konsentrasi ion Besi $\left(\mathrm{Fe}^{2+}\right)$ masing-masing $65,654 \%$; $82,154 \%$; dan $70,767 \%$.

Persentase $(\%)$ penurunan konsentrasi ion Zink $\left(\mathrm{Zn}^{2+}\right)$ pada larutan sampel air Sungai Kopas sebelum penambahan kitosan perak memiliki konsentrasi $0,7218 \mathrm{mg} / \mathrm{L}$ dan setelah penambahan kitosan perak konsentrasi berkurang menjadi 0,3454 ; 0,1092 ; dan $0,2159 \mathrm{mg} / \mathrm{L}$ dengan variasi waktu kontak $30 ; 45$; dan 60 menit. Dengan kata lain, persentase penurunan konsentrasi ion Zink $\left(\mathrm{Zn}^{2+}\right)$ masing-masing $52,147 \% ; \quad 84,871 \%$; dan $70,088 \%$.

Data persentase $(\%)$ penurunan kadar ion $\mathrm{Fe}^{2+}$ dan $\mathrm{Zn}^{2+}$ penambahan kitosan perak dapat dilihat pada tabel 3.3 dan 3.4 dan berdasarkan data tersebut, maka persentase adsorpsi berdasarkan variasi waktu dapat kita lihat pada gambar 5 dibawah ini.

\section{Persentase Adsorpsi Ion Logam $\mathrm{Fe}^{2+}$ dan $\mathrm{Zn}^{2+}$}

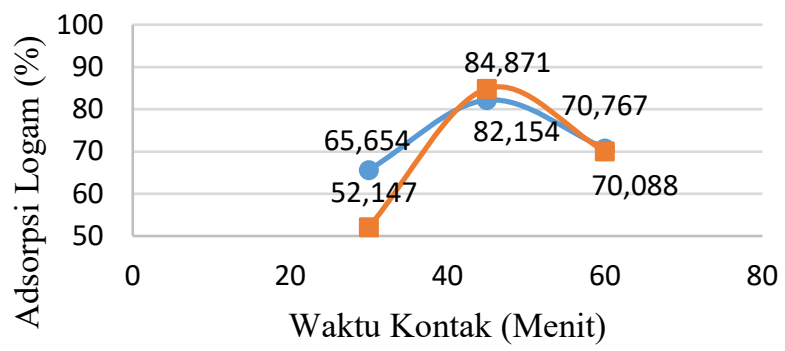

$-\operatorname{Logam} \mathrm{Fe} \quad-\operatorname{Logam} \mathrm{Zn}$

\section{Gambar 7. Grafik Waktu Optimum dengan Persentase Adsorpsi Ion Logam $\mathrm{Fe}^{2+}$ dan $\mathrm{Zn}^{2+}$}

Dari kedua logam yang dianalisa setelah dilakukan perendaman dengan kitosan didapatkan bahwa waktu kontak optimum kitosan perak adalah 45 menit. Pada 30 menit awal, partikel padatan dari sampel belum menempel penuh pada permukaan adsorben, sehingga konsentrasi yang diserap juga tidak terlalu besar. Pada menit ke 45, seluruh pemukaan adsorben telah terisi penuh. Sedangkan pada menit ke 60 , partikel-partikel logam yang telah diserap tadi akan terlepas dari permukaan adsoben dan kembali larut dalam larutan sehingga konsentrasi logam mengalami kenaikan. Proses penyerapan dapat berlangsung ketika permukaan padatan pada molekul adsorbat (zat yang diserap) membentur permukaan adsorben, sehingga sebagian akan menempel di permukaan padatan dan terserap. Pada awalnya, laju adsorpsi cukup besar karena seluruh permukaan masih kosong. Namun permukaan yang terisi oleh 
Harry.et.al. Pembuatan Kitosan Perak Sebagai Adsorben Untuk Menurunkan Kadar Logam Besi (Fe) Dan Zink (Zn) Pada Air Sungai Desa Kopas Kecamatan Simpang Empat Kabupaten Asahan

molekul semakin banyak dan luas daerah kosong semakin menurun, sehingga laju adsorpsinya ikut menurun karena prinsip daerah kosong semakin menurun, sehingga laju adsorpsinya ikut menurun. Hal ini dikarenakan prinsip pertukaran ion kitosan sebagai polimer kationik yang dapat mengikat logam dimana gugus amina yang terdapat pada kitosan berikatan dengan logam dapat membentuk ikatan kovalen. Gaya yang bekerja yaitu gaya Van Der Walls dan gaya elektronik (Widodo, dkk. 2005)

Berdasarkan perbedaan kinerja penyerapan, kitosan perak lebih baik dibandingkan dengan kitosan komersial. Hal ini dikarenakan adanya logam $\mathrm{Ag}$ yang terikat pada gugus $\mathrm{NH}_{2}$ sehingga meningkatkan nilai afinitas dari struktur kitosan perak tersebut.

\section{KESIMPULAN}

Berdasarkan data yang diperoleh pada penelitian ini, maka dapat disimpulkan bahwa:

1. Waktu kontak optimum pada kitosan perak terhadap ion logam Besi $\left(\mathrm{Fe}^{2+}\right)$ dan Zink $\left(\mathrm{Zn}^{2+}\right)$ adalah 45 menit dengan persentase penurunan konsentrasi setelah perendaman berturut-turut adalah $82,154 \%$ dan $84,871 \%$.

2. Hasil penyerapan kitosan perak terhadap ion logam Besi $\left(\mathrm{Fe}^{2+}\right)$ dan Zink $\left(\mathrm{Zn}^{2+}\right)$ menunjukkan bahwa logam $\mathrm{Zn}$ memiliki daya serap yang paling besar, dikarenakan berdasarkan sifat sistem periodik unsur logam $\mathrm{Zn}$ memiliki energi ionisasi lebih besar, keelektronegatifan lebih besar dan kereaktifitas lebih besar dibandingkan unsur logam $\mathrm{Fe}$, sehingga $\mathrm{Zn}$ lebih mudah bereaksi dengan kitosan perak. Hal ini juga dapat dipengaruhi oleh ukuran partikel, konsentrasi, dan suhu yang merupakan faktor-faktor yang mempengaruhi proses adsorpsi.
3. Sebanyak 10 gram Kitosan Perak di dalam $50 \mathrm{~mL}$ sampel Air Sungai Desa Kopas ekuivalen mengikat 0,06 mg logam $\mathrm{Fe}$ dan 0,03 mg logam $\mathrm{Zn}$ pada waktu kontak optimum penyerapan yaitu 45 menit.

\section{UCAPAN TERIMA KASIH}

Kegiatan pengabdian masyarakat yang telah dilaksanakan telah dapat diselesaikan dengan dan didapat hasil yang diharapkan dapat diadopsi oleh masyarakat. Dalam pelaksanaan kegiatan ini, tim peneliti banyak mendapat bantuan dari bebagai kalangan, sehingga kegiatan pengabdian ini dapat terlaksana. Sehubungan dengan hal tersebut, tim peneliti mengucapkan terima kasih kepada LPPM USU yang telah membiayai kegiatan ini.

\section{DAFTAR PUSTAKA}

Agusnar, 2006. Penggunaan Kitosan Dari Tulang Rawan Cumi-Cumi (Loligo pealli) Untuk Menurunkan Kadar Ion Logam Cd Dengan Menggunakan Spektrofotometri Serapan Atom. Jurnal USU. Medan

Ardianto, E. 2009. Metodologi Penelitian Untuk Public Relation Kuantitatif Dan Kualitatif. Edisi pertama. Bandung : Simbiosa Rekatama

Daulay, A.M. 2011. Penggunaan Kitosan Magnetic Nanopartikel Untuk Menyerap Kadmium (Cd) Dan Tembaga $(\mathrm{Cu})$ Dengan Menggunakan Spektrofotometer Serapan Atom. Tesis. Medan : Universitas Sumatera Utara.

Imroatushshoolikhah, Purnama, I.S. dan Suprayogi, S. 2014. Kajian Kualitas Air Sungai CodePropinsi Daerah Istimewa Yogyakarta. Yogyakarta: $\mathrm{M} \mathrm{a} \mathrm{j}$ a 1 a h $\mathrm{G}$ e o g r a $\mathrm{f}$. Junaidi, A. B., Wahyudi, A., Umaningrum, D. 2015. Kajian Sintesis Nanopartikel Perak Pada Komposit Kitosan dan Polietilena Glikol : Efek Jenis Agen Pereduksi Organik. Jurnal Universitas 
Lambung Mangkurat. Surabaya.

Karthikeyan G, Anbalagan K, Muthulakshmi

AN. 2004. Adsorption dynamis and equilibrium studies Antibiotic Delivery. J wiley DOI 10.1002.1260Khopkar, S.M.2003. Kosep Dasar Kimia Analitik. Jakarta: UI Press.

Khairuni, M., 2017. Studi Penggunaan Komposit Kitosan $\mathrm{CuO}$ Sebagai Adsorben untuk Menurunkan Menyerap Logam Besi (Fe), Mangan $(\mathrm{Mn})$, dan Zink (Zn) pada Air Sungai Belawan. USU Press

Maslan. 2011. Efektivitas penyerapan logam besi $(\mathrm{Fe})$ dan Logam Natrium $(\mathrm{Na})$ oleh kitosan nanopartikel pada limbah cair detergen. Tesis. Medan : Universitas Sumatera Utara

Sorrell, T. N. 1998. Interpreting Spectra of Organic Molecules. University of Michingan. United Kingdom.

Suriawiria, U. 2005. Air dalam Kehidupan dan Lingkungan yang Sehat. Bandung: Penerbit PT. Alumni

Widodo, agus, mardiah dan praseto, A. 2005. Potensi Kitosan Dari Sisa Udang Sebagai Koagulan Logam Berat Limbah Cair Industry Tekstil. Surabaya : ITS 